\title{
IN VITRO EVALUATION OF APICAL MICROLEAKAGE USING DIFFERENT ROOT-END FILLING MATERIALS
}

\author{
AVALIAÇÃO IN VITRO DA MICROINFILTRAÇÃO MARGINAL USANDO DIFERENTES \\ MATERIAIS RETROBTURADORES
}

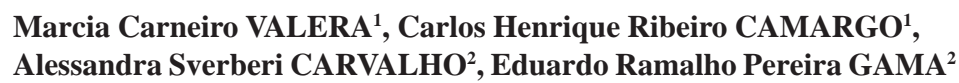

1- DDS, PhD, Dental School of São José dos Campos, São Paulo State University, UNESP, Brazil.

2- DDS, Dental School of São José dos Campos, São Paulo State University, UNESP, Brazil.

Corresponding address: Marcia Carneiro Valera - Av. Eng. Francisco José Longo, 777 - Jd. São Dimas - Cep.: 12.245-000

São José dos Campos - SP - Brazil - e-mail: marcia@fosjc.unesp.br

Received: July 7, 2004 - Modification: January 28, 2005 - Accepted: October 19, 2005

\begin{abstract}
$T$

he objective of this study was to evaluate the apical leakage of retrograde cavities filled with Portland Cement (Concrebrás S/A-MG-Brazil), ProRoot MTA ${ }^{\mathrm{TM}}$ (Dentsply International, Johnson City, TN, USA) and Sealapex (Kerr Corporation, Orange, California, USA) with addition of zinc oxide (Odahcam Herpo Produtos Dentários Ltda, Rio de Janeiro, RJ, Brazil). Forty-two extracted single-rooted human teeth were decoronated and used for this study. The root canals were instrumented at $1.0 \mathrm{~mm}$ short of the apical foramen using the step-back technique to an apical ISO size 60. The roots were obturated with gutta-percha points and sealer Sealapex (Kerr Corporation-USA) and then $3 \mathrm{~mm}$ of each root apex was sectioned at a $90^{\circ}$ angle. Ultrasonic retrograde preparation was performed with a diamond tip to $3 \mathrm{~mm}$ depth and the roots were randomly divided into 3 groups according to the filling material: G1-Portland, G2-ProRoot MTA, G3- Sealapex zinc oxide-added cement. The root surfaces were covered with nail varnish up to $2 \mathrm{~mm}$ from the apical foramen, immersed in simulated tissue fluid for 30 days, and then immersed in $0.2 \%$ Rhodamine B solution for 24 hours for evaluation of marginal leakage. The results showed mean leakage of 0.75 , 0.35 and 0.35 for groups 1, 2 and 3, respectively; however, Kruskal-Wallis test revealed that there was no statistically significant difference among the results ( $\mathrm{p}>0.05)$.

Uniterms: Dental leakage; Root canal filling materials; Retrograde obturation.
\end{abstract}

\section{RESUMO}

$O$

objetivo deste trabalho foi avaliar o selamento marginal de cavidades retroapicais obturadas com os cimentos Portland (Concrebrás S/A-MG-Brasil), MTA ${ }^{\mathrm{TM}}$ (Dentsply International, Johnson City, TN, EUA) e Sealapex ${ }^{\mathrm{TM}}$ (Kerr Corporation, Orange, California, EUA) acrescido de óxido de zinco (Odahcam Herpo Produtos Dentários Ltda, Rio de Janeiro, RJ, Brasil). Foram utilizados 42 dentes unirradiculados humanos extraídos que, após a remoção de suas coroas, tiveram seus canais preparados a $1 \mathrm{~mm}$ aquém do ápice radicular até o instrumento $\mathrm{n}^{\circ}$ 60. Os canais foram obturados com cones de guta-percha e cimento Sealapex $^{\mathrm{TM}}$ e, em seguida, foi realizado o seccionamento de $3 \mathrm{~mm}$ do ápice radicular em ângulo de $90^{\circ}$ em relação ao longo eixo do dente. Foram preparadas cavidades retroapicais com ponta diamantada em ultrasom, a uma profundidade de $3 \mathrm{~mm}$, e as raízes foram divididas aleatoriamente em 3 grupos de acordo com o material retrobturador: G1- Portland, G2 - MTA, G3 - Sealapex acrescido de óxido de zinco. As raízes foram impermeabilizadas externamente e imersas em fluido tissular simulado por 30 dias. Em cada grupo, 2 dentes serviram como controle positivo (não impermeabilização) e negativo (total impermeabilização). Os espécimes foram imersos em corante Rhodamina B 0,2\% por 24 horas para avaliação da infiltração marginal. Os cimentos Portland, Sealapex ${ }^{\mathrm{TM}}+$ óxido de zinco e MTA apresentaram média de infiltração de 0,75; 0,35 e 0,35mm respectivamente, não havendo diferenças estatísticas significantes entre eles $(\mathrm{p}>0,05)$.

Unitermos: Infiltração dentária; Materiais restauradores do canal radicular; Obturação retrógrada. 


\section{INTRODUCTION}

One of goals of root canal obturation is to obtain hermetic sealing of the root canal system, favoring the process of apical and periapical repair after endodontic therapy. Inadequate filling can result in fluid movements into the filling defects, inducing a periapical chronic inflammatory reaction and compromising the treatment success. Other factors lead to failures sometimes not resolvable through the intracanal therapy, such as drilling accidents and root resorptions. Therefore, in some situations, surgical complementation is necessary in order to obtain apical repair. Therefore, several surgical techniques were proposed, including them apicoectomy followed by retrograde filling.

Many materials have been proposed for utilization in retrograde fillings as amalgam ${ }^{2,4,11,12,16,17,20,21,23}$, calcium hydroxide based cements ${ }^{5,13,14}$, zinc oxide and eugenol ${ }^{2,4,13}$

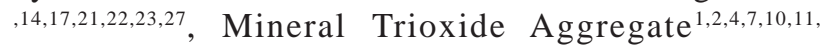
12,13,14,20,21,22,23,25 , resins $^{13}$, and Portland cement ${ }^{7,11}$. This new proliferation of materials raised doubts about their use, mainly because until now an ideal material that presents adequate physical-chemical and biological properties, such as easy manipulation, dimensional stability, non toxicity, radiopacity, non resorbability, not being affected by the presence of humidity and able to stimulate the repair of apical tissue ${ }^{3}$, has not been achieved in the literature. The Mineral Trioxide Aggregate (MTA) has been shown to be better than other retrograde filling materials with regard to citotoxicity $^{14}$, sealing ${ }^{25}$, marginal adaptation ${ }^{22}$ and induction of periodontal ligament repair ${ }^{12}$. Besides, Portland cement has been shown to have similar biological properties compared with MTA and calcium hydroxide ${ }^{10}$.

The objective of this study was to evaluate the apical leakage of root-end preparations filled with Portland cement (Concrebrás S/A, Montes Claros, MG, Brazil), Sealapex ${ }^{\mathrm{TM}}$ (Kerr Corporation, Orange, California, USA) with addition of zinc oxide (Odahcam - Herpo Produtos Dentários LTDA, Rio de Janeiro, RJ, Brazil) and Mineral Trioxide Aggregate ProRoot MTA ${ }^{\mathrm{tm}}$ (Dentsply International, Johnson City, TN, USA).

\section{MATERIALAND METHODS}

In this study, forty-two single-rooted human teeth extracted for several reasons and selected according to their external and internal anatomy were used. The teeth were maintained in $10 \%$ formalin solution for 24 hours and transferred to saline solution at the time of use. Them, they were cleaned and their crowns cut off close to the cementoenamel junction with a carborundum disc at low speed under water coolant. A K-File \#10 (Maillefer-Swiss Company) was inserted into the root canal to locate and unblock the apical foramen.

Each root canal was cleaned with $1 \% \mathrm{NaOCl}$ and shaped to a \#60 K-file at the working length, using the step-back technique. Then, the root canals were dried with absorbent points (Tanari- LTDA- Brazil) and obturated with gutta- percha (Tanari- LTDA- Brazil) and Sealapex (Kerr Corporation-USA) root canal sealer using lateral condensation technique. The roots were X-rayed to verify the complete filling of the root canal.

The tip of each root was resected perpendicular to its long axis 3mm from the apex with diamond bur \#1090 ( KG Sorensen, São Paulo, SP, Brazil) using a high speed hand piece with water coolant using a proper apparatus (supports developed by the Department of Restorative Dentistry, UNESP, São José dos Campos, SP, Brazil). Then apical cavities with the depth of 3mm were prepared ultrasonically (NAC Plus Adiel Comercial, Ribeirão Preto, SP, Brazil) by a DF 608 diamond tip (Multisonic S Gnatus, Satelec system $n^{\circ}$ S12.900 - Gnatus, Ribeirão Preto, SP, Brazil).

The root surfaces were covered with two layers of nail varnish ( Risqué,Taboão da Serra, SP, Brazil) up to $2 \mathrm{~mm}$ from the apical foramen and then divided into 3 groups with 14 specimens each, according to retrograde filling material used:

Group 1: Portland cement (Concrebrás, Montes Claros, MG, Brazil).

Group 2: Mineral Trioxide Aggregate - ProRoot ${ }^{\mathrm{tm}}$ MTA (Dentsply International, Johnson City, TN, USA).

Group 3: Sealapex ${ }^{\mathrm{tm}}$ (Kerr Corporation, Orange, California, USA) with zinc oxide added. (Odahcam-Herpo Produtos Dentários LTDA, Rio de Janeiro, RJ, Brazil).

Portland cement was mixed by adding distilled water to the powder at the same proportion recommended by the manufacturer of ProRoot MTA. The Sealapex was prepared by mixing equal parts of the base paste, catalyst and zinc oxide until a homogenous color was obtained. The zinc oxide was then added until uniformity was obtained using 1:1:1 proportion of base paste, part catalyst and zinc oxide. All materials were inserted into the apical cavity with spatula \#1 adapted with an amalgam condenser, and the excesses removed with sterile gauze.

The roots were externally covered with a layer of approximately $2 \mathrm{~mm}$ of sticky wax except for the apical section. In each group, two specimens were used as positive and negative internal controls. For the positive control, the external root surface of a specimen was not covered with any varnish or wax. For the negative internal control, the external surface was completely covered, including the apical section.

The roots were immersed in simulated tissue fluid (chloride of sodium-100mM of chloride of potassium-4mM; chloride of calcium-1mM; sulfide of magnesium-1mM), buffered and with $\mathrm{pH}$ adjusted at 7.4 , maintained at $37^{\circ} \mathrm{C}$ and $100 \%$ relative humidity for 30 days. During this period, the tissue fluid was changed weekly using sterile vats and a laminar-flow chamber (Veco of Brazil - Marconi laboratory equipments - Brazil). After this period, the roots were removed from the simulated tissue fluid, rinsed with saline solution and immersed in $0.2 \%$ Rhodamine B dye.

The dye was applied in a vacuum environment of $20 \mathrm{~mm}$ Hg maintained by a vacuum pump model CAL BF - 1725 (Dia Pump Fanen Ltda, São Paulo, SP, Brazil) connected to a dehumidifier. The samples were kept in the vacuum for one 
hour and then were maintained in the dye at $37^{\circ} \mathrm{C}$ and $100 \%$ relative humidity for 24 hours. After the time elapsed for remaining in the dye, the roots were washed in running water, dried and the external layers of varnish and wax were removed. The roots were then split up to the middle, in buccolingual direction, obtaining two halves with the path of the root canal especially evident in the apical third. The samples were mounted individually on glass microscope slides and evaluated on a stereomicroscope (Tecnival Carl Zeiss - JENA - Germany) with micrometric measurement ocular for evaluation of the linear dye penetration at the tooth-materials interface.

Statistical analysis of the data was accomplished using non-parametric Kruskal-Wallis test $(\mathrm{p}<0.05)$

\section{RESULTS}

The mean dye penetration values $(\mathrm{mm})$ are shown in Table 1.

The results were analyzed by non-parametric KruskalWallis test at a significance level of 5\%. ( $>00.05)$. Although the extent of dye penetration was similar in apical cavities obturated with MTA and Sealapex $+\mathrm{ZnO}(0.350 \pm 0.189$ and $0.350 \pm 0.584$, respectively) and highest in Portland group $(0.750 \pm 0.897)$, there were no statistically significant differences between groups ( $\mathrm{p}>0.05$ ).

\section{DISCUSSION}

The results of the present study showed that the three experimental materials presented similar marginal sealing ability.

The Mineral Trioxide Aggregate (MTA) was developed by Torabinejad, et al. ${ }^{20}, 1999$, who verified low leakage in retrograde cavities filled with this material. Since then, several studies have shown its excellent capacity of marginal sealing when compared with other materials (Abedi and Ingle ${ }^{1}, 1995$; Torabinejad, et al. ${ }^{21}$, 1995; Bates, et al. ${ }^{4}, 1996$; Yatsushiro, et al. ${ }^{25}$, 1998; Torabinejad and Chivian ${ }^{20}$, 1999; Wucherpfennig $^{26}$, 1999; Aqrabawi², 2000). The main components of MTA are tricalcium silicate, tricalcium aluminate, tricalcium oxide and silicate oxide. The powder is composed of small hydrophilic particles and the hydration of the powder results in a colloidal gel that solidifies in the mineralized structure of the tooth (Torabinejad, et al. ${ }^{22}$,1993), leading to a marginally satisfactory adaptation due to the possible expansion of this material in a humid environment.

The studies of Abedi, et al. ${ }^{1}$,1995; Holland, et al. ${ }^{9}$,1998; ; Wucherpfennig $^{26}, 1999$; Estrela, et al. ${ }^{7}$, 2000; Keiser, et al. ${ }^{12}, 2000$; Holland, et al. ${ }^{10,11}$, 2001 were done in order to evaluate the biological compatibility of MTA to the periapical tissues when compared to other retrograde-filling materials. In these studies it was verified that MTA presented lower toxicity than Super-EBA, amalgam and IRM, materials traditionally used for retrograde filling (Keiser, et al. ${ }^{14}$, 2000; Abedi, et al. ${ }^{1}$,1995), as well as providing a favorable treatment for the periapical tissues with new cement formation around them (Zhu, et al. ${ }^{27}$, 2000; Abedi and Ingle ${ }^{1}$, 1995).

The results obtained in the present study did not show statistically significance difference.

Portland cement has shown very similar antimicrobial properties to MTA (Estrela, et al. ${ }^{7}, 2000$ ). Besides Estrela, et al. ${ }^{7}, 2000$ and Funteas, et al. ${ }^{8}, 2003$ verified that the components of these two cements are similar, except for the presence of bismuth, used to improve radiopacity of MTA.

Holland, et al. ${ }^{10,11}$, 2001, observed a very similar behavior between Portland cement and MTA, both inducing mineralized tissue deposition in dogs' pulps $^{11}$ and in the connective tissue of mice ${ }^{10}$.

However, we cannot compare these results with others in the literature since we are dealing with a recent material for endodontic use and many doubts still exist regarding their composition and behavior. It was also verified that Portland cement was similar to MTA with regards to manipulation, time of work, consistence and appearance of the material (Estrela, et al. ${ }^{7}$ 2000).

The cement Sealapex plus zinc oxide also presented similar leakage as the other materials. For utilization in root canal filling, it required addition of zinc oxide to allow adequate consistency for insertion into the cavity. Tanomaru Filho, et al. ${ }^{19} 1998$, observed in vitro better retrograde sealing with Sealapex and Sealer 26 compared with zinc oxide and eugenol. This material showed good antimicrobial activity (Tanomaru, et $\mathrm{a}^{18}$ 2003) and better tissue tolerance in mouse with the Sealapex without zinc oxide ( Valera, et al. ${ }^{24}$ ).

Leonardo, et al. $.^{15}, 1997$, studied the evolution of the apical and periapical repair processes after endodontic treatment with calcium-hydroxide based cements, and Sealapex was the cement that allowed larger mineralized tissue deposition at the periapical level, being also the only cement capable of accomplishing complete sealing. Also Holland, et al. ${ }^{9}, 1998$, verified in vital pulpectomies in dogs that Sealapex presented

TABLE 1- Mean dye penetration values

\begin{tabular}{llll}
\hline & $\begin{array}{l}\text { Portland } \\
\mathrm{n}=\mathbf{1 2}\end{array}$ & $\begin{array}{l}\text { MTA } \\
\mathrm{n}=\mathbf{1 2}\end{array}$ & $\begin{array}{l}\text { Sealapex+ZnO } \\
\mathrm{n}=\mathbf{1 2}\end{array}$ \\
\hline Min. Leakage & 0.100 & 0.000 & 0.200 \\
Max. Leakage & 3.500 & 0.700 & 2.000 \\
Mean \pm SD & $0.750 \pm 0897$ & $0.350 \pm 0.189$ & $0.350 \pm 0584$ \\
\hline
\end{tabular}


excellent results, with biological closing of the apex. Tanomaru Filho, et al. ${ }^{17}, 1998$ included Sealapex in a study of periapical repair in teeth with periapical chronic periodontitis, and the results of histopathological repair were significantly better compared to zinc oxide and eugenol-based cements.

It should be emphasized that the exact clinical importance of leakage studies is still unknown, requiring the use of materials that promote minimal in vitro leakage in association with the biological properties.

\section{CONCLUSION}

The results of this study showed that all materials tested were unable to avid dye penetration. Despite the differences between the mean leakage of Portland cement compared with MTA and Sealapex zinc oxide-added cement, all groups were equally ineffective to avoid dye penetration.

\section{REFERENCES}

1- Abedi HR, Ingle JI. Mineral trioxide aggregate: a review of a new cement. J Calif Dent Assoc. 1995;23(12):36-9.

2- Aqrabawi J. Sealing abillity of amalgam, Super-EBA cement and MTA when used as retrograde filling materials. Br Dent J. 2000;188(5):266-8.

3- Arens DE, Torabinejad M, Chivian N, Rubistein R. Practical lessons in endodontic surgery. Carol Stream: Quintessence; 1998.

4- Bates CF, Carnes DL, Del Rio CE. Longitudinal sealing ability of mineral trioxide aggregate as a root-end filling material. J Endod. 1996; 22(11) 575-8.

5- Cardoso RJA, Machado MEL. Dentistica: arte e conhecimento. São Paulo: Artes Médicas; 2003.

6- Castellucci A. The use of mineral trioxide aggregate in clinical and surgical endodontics. Dent Today. 2003;22(3):74-81.

7- Estrela C, Bammann LL, Estrela CRA, Silva RS, Pécora JD. Antimicrobial and chemical study of MTA, Portland, calcium hidroxyde paste, sealapex and dycal. Braz Dent J. 2000;11(1):3-9.

8- Funteas UR, Wallace JA, Fochtman EW. A comparative analysis of Mineral Trioxide Aggregate and Portland cement. Aust Endod J. 2003;29(1):43-4.

9- Holland R, Otoboni Filho JA, Souza V, Nery MJ, Bernabé PFE, Dezan Junior E. Calcium hydroxide and a corticosteroid-antibiotic association as dressing in cases of biopulpectomy. A comparative study in dogs' teeth. Braz Dent J. 1998;9(1):67-76.

10- Holland R, Souza V, Nery MJ, Faraco Júnior IM, Bernabé PFE, Otoboni Filho JA, Dezan Júnior E. Reaction of rat connective tissue to implantes dentin tube filled with Mineral Trioxide Aggregate, Portland Cement or Calcium Hydroxide. Braz Dent J. 2001;12(1):38 .

11- Holland R, Souza A V, Murata SS, Nery MJ, Bernabé PFE, Otoboni Filho JA, Dezan Júnior E. Healing process of dog dental pulp after pulpotomy and pulp covering with Mineral Trioxide Aggregate or Portland cement. Braz Dent J. 2001;12(2):109-13.

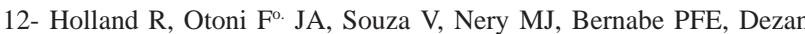
Jr E. Mineral trioxide aggregate repair of lateral root perforations. J Endod. 2001;27(4):281-4.
13- Johnson BR. Considerations in the selection of a root-end filling material. Oral Surg Oral Med Oral Pathol. 1999;87(4):398-404.

14- Keiser K, Johnson C, Tipton DA. Cytotoxicity of Mineral Trioxide Aggregate using human periodontal ligament fibroblasts. J Endod. 2000;19(12):288-91.

15- Leonardo MR, Silva LAB, Utrilla LS, Assed S, Ether SS. Calcium hydroxide root canal sealers - histopathologic evaluation of apical and periapical repair after endodontic treatment. J Endod. 1997;23(7):428-32.

16- Saidon J, He J, Zhu Q, Safavi K, Spängberg LSW. Cell and tissue reactions to Mineral Trioxide Aggregate and Portland Cement. Oral Surg Oral Med Oral Pathol. 2003;95(4):483-9.

17- Tanomaru Filho M, Leonardo MR, Silva LAB, Utrilla LS. Effect of different root canal sealers on periapical repair of teeth with chronic periradicular periodontitis. Int Endod J. 1998;31(2):85-9.

18- Tanomaru JMG, Tanomaru Filho M, Tellaroli VM, et al. Atividade antimicrobiana in vitro de materiais obturadores e retrobturadores. J Bras Endod. 2003;4(14):237-41.

19- Tanomaru Filho M, Bonzi ES, Wilhelmsen NSW, Ogata M. Capacidade seladora de diferentes cimentos endodônticos em obturações retrógradas. Rev Fac Odontol Lins. 1998;11(1):58-61.

20- Torabinejad M, Chivian N. Clinical applications of mineral trioxide aggreggate. J Endod. 1999; 25(3):197-205.

21- Torabinejad M, Hong CU, Mcdonald F, Pitt Ford TR. Physical and chemical properties of a new root-end filling material. J Endod. 1995;21(7):349-53

22- Torabinejad M, Smith PW, Kettering JD, Pitt Ford TR. Comparative investigation of marginal adaptation of Mineral Trioxide Aggregate and other commonly used root-end filling materials. J Endod. 1995;21(6):295-8.

23- Torabinejad M, Watson TF, Pitt Ford TR. Sealing ability of a mineral trioxide aggregate as a root end filling material. J Endod. 1993;19:591-5.

24- Valera MC, Anbinder AL, Consolaro A, Bonetti Filho I. Estudo da compatibilidade biológica em tecido conjuntivo de ratos, do cimento endodôntico Sealapex puro e acrescido de iodofórmio ou óxido de zinco. Braz Dent Sci. 2005;8(4):29-38.

25- Yatsushiro JD, Baumgartner C, Tinkle JS. Longitudinal study of two root-end filling materials using a fluid conductive system. J Endod. 1998;24(11):716-821.

26- Wucherpfennig AL. Mineral trioxide vs. Portland cement: two biocompatible filling materials. J Endod. 1999;25(4):308.

27- Zhu Q, Haglund R, Safavi KE, Spängberg LSW. Adhesion of human osteoblasts on root-end filling materials. $\mathrm{Br}$ Dent $\mathrm{J}$. 2000;188(5):266-8. 